\title{
Praktek Prostitusi Terhadap Penyalahgunaan Izin SPA
}

\author{
Rasyid \\ St. Fatimah Tola \\ Universitas Muhammadiyah Makassar \\ fatimahtola@unismuh.ac.id \\ Ruliati \\ Universitas Muhammadiyah Makassar \\ ruliati@unismuh.ac.id
}

\begin{abstract}
ABSTRAK
Permasalahan yang diangkat oleh peneliti yaitu di mana para pemilik tempat spa di Makassar selalu menyalahgunakan izin spa yang di pergunakan bukan untuk sebagaimana mestinya dan tujuan peneliti agar meminimalisir oknum-oknum yang menyalahi aturan perda yang berlaku di kota Makassar. Jenis penelitian ini merupakan penelitian kualitatif yang bersifat deskriptif yang berupaya untuk mengetahui suatu permasalahan yang ada di tempat spa di kota Makassar.dengan menggunakan teknik pengumpulan data melalui observasi , wawancara dan dokumentasi. Hasil penelitian wawancara tersebut dapat di simpulkan bahwa dalam pemberian izin SPA di Makassar cukup optimal dalam meminimalisir tempat-tempat yang di indikatorkan terjadi tindakan prostitusi didalamnya,hal ini dapat di lihat dengan banyaknya razia-razia yang di lakukan di tempat spa yang ada di kota Makassar.meskipun sudah ada penyuluhan aturan tentang usaha spa namun masih banyak oknum-oknum pengusaha spa yang tetap melanggar aturan yang sudah ada seperti teori anomie Robert $\mathrm{k}$ merton dan dari factor socialnya sendiri banyaknya orang yang berkerja sebagai pelaku prostitusi karena lebih menjanjikan dalam segi ekonomi dalam membantu keuangan keluarga dan kehidupan sehari-hari walaupun berisiko besar tetap di jalani tanpa memikirkan dirinya sendiri.
\end{abstract}

Kata Kunci : Praktek, Prostitusi, Penyalahgunaan Izin

\section{PENDAHULUAN}

Prostitusi merupakan fenomena yang sudah ada sejak lama didunia, tidak berlebihan jika dikatakan bahwa prostitusi menjadi salah satu jenis pekerjaan tertua didunia, termasukyang ada di Indonesia.Prostitusi di Indonesia sendiri bermula sejak zaman kerajaan-kerajaan Jawa yang menggunakan wanita sebagai bagian dari komoditas sistem feodal. Pada zaman modern praktik prostitusi berkembang pesat dengan mudah didapati di tempat hiburan malam baik di perkotaan maupun didesa-desa.perkembangan praktik prostitusi yang tidak saja hanya terfokus pada tempat lokalisasi semata melainkan juga dijalankan secara terbuka maupun tersumbunyi oleh tempat-tempat pelayan seperti panti pijat, kios maupun rumah-rumah singgah minum kopi. Praktik prostitusi yang tumbuh berkembang mempunyai alasan yang sangat beragam. Pada peristiwa pelacuran itu ada dorongan-dorongan seks yang tidak terintegrasi dengan kepribadian. Artinya, implus- implus seks itu tidak terkendali oleh hati nurani.Selanjutnya, dipakailah teknik- 
teknik seksual yang amat kasar dan provokatif dalam sanggama, dan sangat impersonal karena berlangsung efeksi tanpa perasaan, emosi dan kasih sayang, sehingga dilakukan dengan cepat, dan tanpa orgasme pada pihak wanita/pelacurnya.

Makassar Sebagai kota modern sudah bukan menjadi rahasia umum jika terdapat banyak tempat yang menyediakn jasa prostitusi. Ada beberapa lokasi di kota Makassar yang menyiapkan jasa prostitusi seperti dijalan Nusantara, dan Jalan Sungai Sadang, jalan Serigala, jln Gunung Bulusaraung, jalan Serigala dan jalan Rusa.Prostitusi berkedok panti pijat, SPA, pub, kafe dan tempat karaokean, hingga salon. Disemua tempat ini disediakan wanita-wanita cantik dan seksi, mereka siap memuaskan para lelaki hidung belang. Praktik prostitusi terselubung di Makassar sudah menjadi rahasia umum. Ada beberapa tempat di kota Makassar yang menyiapakan wanita pemuas nafsu. Kebanyak berkedok panti pijat, SPA, Pub, kaf dan tempat karokean hingga salon. Disemua tempat ini disediakan wanita-wanita cantik dan seksi.Mereka siap memuaskan para lelaki hidung belang dan yang terbanyak menerapkan praktik terselubung dikota Makassar adalah panti pijat. Beberapa lokasi seperti dikawasan Panakukang, jalan gunung Bulusaraung, jalan serigala dan rusa. Modus dalam pelaksanaan setiap tempat berbeda-beda dalam menjaring dan melaksanakan kegiatan prostitusi, Tempat pijat misalnya, menyiapkan kamar-kamar plus wanita "Pelacur" yang siap memberikan pelayanan plus-plus selain pijat.Tentu saja, sebelum melakukan hubungan seks terlebih dahulu dilakukan nego tarif sekali kencan.Tentunya, agar tidak diketahuan ataupun mengelabui petugas, disetiap kamar dipasang kertas besar bertuliskan, "Dilarang berbuat asusila”.Namun, wanita yang bertugas melayani lelaki hidung belang tidak langsung menawari pelanggannya melakukan hubungan seks. Tetapi terlebih dahulu membe rikan rangsangan sehingga membuat pelanggan yang meminta sang wanita memberikan layanan plus-plus.

Pihak Polri tentu tidak akan membiarkan hal ini terus terjadi, karena selain hal ini melanggar hukum, juga berdampak negatif bagi masyarakat kota makassar, terlebih warga yang bermukiman disekitar lokasi tersebut. Mengingat pelacuran ini merupakan bisnis gelap maka penyelesaian dan penanganan masalah ini semakin rumit, apalagi pelacuran merupakan bisnis perdagangan tanpa adanya barang yang diperdagangkan dan dilakukan di tempat tertutup sehingga untuk membuktikan telah terjadinya hal tersebut sangat sulit. Tetapi sulit tidak sama dengan mustahil, untuk itu walaupun penanganan masalah pelacuran ini sulit kita tetap harus berusaha untuk menyelesaikan masalah tersebut. 


\section{LANDASAN TEORI}

Salah satu perilaku menyimpang yang sering dialami dalam masyarakat yaitu Prostitusi atau pelacuran yang dimana memiliki aturan penjualan jasa seksual, seperti seks oral atau hubungan seks, untuk uang.Seseorang yang menjual jasa seksual disebut pelacur, yang kini sering disebut dengan istilah pekerja seks komersial (PSK). Pelacur wanita disebut prostitue, sundal, balon, lonte; sedangkan pelacur pria biasa disebut gigolo.Ditinjau dari sudut psycopathologic, prostitusi adalah suatu kelakuan yang menyimpang dari norma-norma susila, dalam arti kata tidak sesuai dengan norma-norma susila.

Pelacuran berasal dari bahasa Latin pro-stituere atau pro-stauree yang berarti membiarkan diri berbuat zina, melakukan persundalan, percabulan dan pergendakan. Perkins dan Bennet dalam Koendjoro (2004: 30), mendefinisikan pelacuran sebagai transaksi bisnis yang disepakati oleh pihak yang terlibat sebagai sesuatu yang bersifat kontrak jangka pendek yang memungkinkan satu orang atau lebih mendapatkan kepuasan seks dengan metode yang beraneka ragam. Senada dengan hal tersebut, Supratiknya (1995: 97) menyatakan bahwa prostitusi atau pelacuran adalah memberikan layanan hubungan seksual demi imbalan uang.

Pelacur dapat berasal dari kalangan wanita yang lebih dikenal dengan wanita tuna susila (WTS) dan dari kalangan laki-laki yang lebih dikenal dengan sebutan gigolo.Koentjoro (2004: 27) mendefinisikan wanita tuna susila (WTS) sabagai perempuan yang tidak menuruti aturan susila yang berlaku di masyarakat dan dianggap tidak memiliki adap dan sopan santu dalam berhubungan seks.Sedangkan gigolo dijelaskan secara singkat yang dipahami sebagai laki-laki bayaran yang dipelihara atau disewa oleh seorang perempuan sebagai kekasih ataupasangan seksual.

Kemudian secara rinci Kartini Kartono (2005: 245) menjelaskan motif-motif yang melatar belakangi pelacuran pada wanita adalah (1) Adanya kecenderungan melacurkan diri pada banyak wanita untuk menghindarkan diri dari kesulitan hidup, dan mendapatkan kesenangan melalui jalan pendek. Kurang pengertian, kurang pendidikan, dan buta huruf, sehingga menghalalkan pelacuran. (2) Ada nafsu-nafsu seks yang abnormal, tidak terintegrasi dalam kepribadian, dan keroyalan seks. Hysteris dan hyperseks, sehingga tidak merasa puas mengadakan relasi seks dengan satu pria/suami. (3) Tekanan ekonomi, faktor kemiskinan, dan pertimbangan-pertimbangan ekonomis untuk mempertahankan kelangsungan hidupnya, khususnya dalam usaha mendapatkan status sosial yang lebih baik. (4) Aspirasi materiil yang tinggi pada diri wanita dan kesenangan ketamakan 
terhadap pakaian-pakaian indah dan perhiasan mewah. Ingin hidup bermewah-mewah, namun malas bekerja. (5) Kompensasi terhadap perasaan-perasaan inferior. Jadi ada adjustment yang negatif, terutama sekali tarjadi pada masa puber dan adolesens. Sehingga faktor-faktor yang melatarbelakangi seseorang memasuki dunia pelacuran dapat dibagi menjadi dua, yaitu faktor internal dan faktor eksternal. Faktor internal berupa rendahnya standar moral dan nafsu seksual yang dimiliki orang tersebut. Sedangkan faktor eksternal berupa kesulitan ekonomi, korban penipuan, korban kekerasan seksual dan keinginan untuk memperoleh status sosial yang lebih tinggi, pelacuran tersebut dapat disalurkan melalui beberapa tempat seperti tempat prostitusi resmi dan tidak resmi seperti hanya dengan tempat SPA.

SPA yang kemudian menjadi salah satu usaha yang bertujuan dalam merileksasi, menyembuhkan ataupun mempercantik/tampan menjadi gaya hidup masyarakat modern perkotaan. Dalam prakteknya SPA memanjakan pengujung dalam memoles tubuh, pijatan dengan tujuanmelemaskan otot-otot tubuh yang tegang, sekaligus menghilangkan stres. Hingga menghasilkan kesegaran pikiran dan menyehatkan tubuh.

SPA di kota Makassar diatur melalui peraturan pemerintah daerah Makassar berdasarkan ketentuan Peraturan Pemerintah nomor 52 tahun 2012 pasal 17 ayat 1 dan ayat 2 tentang sertifikasi kompetensi dan usaha dibidang pariwisata. Adapun penggolongan dan penyelenggaran usaha SPA terbagi ats 3, yaitu SPA tirta 3. SPA tirta 2, dan SPA tirta 1. Izin usaha SPA yang sebenarnya adalah tempat dimana orang dapat memperoleh perawatan-perawatan untuk badan, dari ujung rambut sampai ujung kaki. Perawatan tersebut terdiri dari creambath, facial, manicure-pedicure, lulur, scrub, foot spa, sauna, dan body treatment, sampai memperlancar aliran darah. Namun terkadang apa yang menjadi tujuan sebenarnya hanya merupakan kedok atau penipuan semata dalam hal ini menjadi ketertarikan penulis yang akrab mendengar dan melihat usaha SPA sebagai ajang transaksi prostitusi. Lebih lanjut, adalah benar dalam kajian advertaising, iklan disedian pihak usaha dalam menjaring pelanggaan dengan upaya memberlakukan pijat refleksi plus plus. Penyalahgunaan izin spa dikemudian hari banyak bermain aspek-aspek pendorong, mulai dari strtegi pemasaran, pelyanan dan ada yang memang sebagai tempat penyaluran hasrat seksual yang non illegal.SPA menjadi sarana yang tepat dikarenakan ada celah yang mana dapat dimanfatkan dalam meraup keuntungan diluar kegiatan reflektif dan kesehatan.

SPA menjadi tempat prostitusi sudah menjadi rahasia umum dikalangan masyarakat, image yang digunakan pelaku usaha dan pengguna aman dikarenakan 
tersamar dengan diketahui usaha Spa sebagai usaha pijat saja yang pada faktanya melakukan service pelayanan lain. Baik pemilik, karyawan dan pengguna jasa tidak merasa akan diketahui masyarakat luas secara terang-terangan jika menggunakan nama SPA bandingkan dengan izin usaha yang legal, maupun karyawan dalam prostitusi yang didata identitasnya.

\section{METODE PENELITIAN}

Adapun jenis penelitian yang digunakan ialah deskriptif kualitatif, yaitu penelitian dengan memberikan gambaran secara jelas dan sistematis terkait dengan objek yang diteliti, dengan menggunakan pendekatan deskriptif eksploratif Penentuan informan dalam penelitian ini dilakukan dengan teknik proposive sampling dan snowball sampling, dan juga menggunakan sumber data primer dan data sekunder, teknik pengumpulan data yaitu observasi, wawancara dan dokumentasi, kemudian dianalisis melalui tahapan pengorganisasian data, pengelompokan data, menguji asumsi terhadap permasalahan yang ada terhadap data, mencari alternatif penjelasan data, menuliskan hasil penelitian, sedangkan teknik keabsahan datanya menggunakan triangulasi sumber, waktu, metode dan teknik.

\section{PEMBAHASAN}

Bertolak dari rumusan masalah dalam penelitian yang telah dilakukan kepada Praktek Prostitusi Terhadap Penyalahgunaan Izin Spa Di Makassar Dalam Tinjauan Sosio-Ekonomi" melalui kegiatan observasi, wawancara dan dokumentasi terhadap informan yang telah ditetapkan sebelumnya sebagai informan peneliti yang merupakan sumber informan utama. Dapat disajikan hasil penelitian mengenai Praktek Prostitusi Terhadap Penyalahgunaan Izin Spa Di Makassar Dalam Tinjauan Sosio-Ekonomi” dapat dibahas sebagai berikut:

\section{Praktek prostitusi terhadap penyalahgunaan izin SPA di Makassar dalam tinjauan Sosio ekonomi.}

Pelacuran merupakan salah satu fenomena sosial dalam masyarakat yang sangat kompleks, baik dari segi sebab-sebabnya, prosesnya maupun implikasi soasial yang ditimbulkannya. Pelacuran dengan berbagai versinya merupakan bisnis yang abadi sepanjang zaman. Karena disamping disebut sebagai profesi yang tertua, jasa pelacuran pada hakekatnya tetap dicari oleh anggota masyarakat yang tidak terpenuhi kebutuhan seksualnya. Karena itu pelacuran memerlukan penanganan komprehensif dari berbagai 
pihak. Prostitusi atau pelacuran sebagai salah satu penyakit masyarakat mempunyai sejarah yang panjang (sejak adanya kehidupan manusia telah diatur oleh norma-norma perkawinan, sudah ada pelacuran sebagai salah satu penyimpangan dari pada normanorma perkawinan tersebut) dan tidak ada habis-habisnya yang terdapat di semua negara di dunia. Walaupun prostitusi sudah ada sejak dulu, namun masalah prostitusi yang dulu dianggap tabu atau tidak biasa. Namun masa jaman sekarang prostitusi oleh masyarakat Indonesia dianggap menjadi sesuatu yang biasa. Prostitusi atau pelacuran sebagai salah satu penyakit masyarakat mempunyai sejarah yang panjang (sejak adanya kehidupan manusia telah diatur oleh norma-norma perkawinan, sudah ada pelacuran sebagai salah satu penyimpangan dari pada norma-norma perkawinan tersebut) dan tidak ada habishabisnya yang terdapat di semua negara di dunia. Walaupun prostitusi sudah ada sejak dulu, namun masalah prostitusi yang dulu dianggap tabu atau tidak biasa. Namun masa jaman sekarang prostitusi oleh masyarakat Indonesia dianggap menjadi sesuatu yang biasa.

Permasalahan lebih menjadi rumit lagi tatkala pelacuran dianggap sebagai komoditas ekonomi (walaupun dilarang UU) yang dapat mendatangkan keuntungan finansial yang sangat menggiurkan bagi para pebisnis. Pelacuran telah diubah dan berubah menjadi bagian dari bisnis yang dikembangkan terus-menerus sebagai komoditas ekonomi yang paling menguntungkan, mengingat pelacuran merupakan komoditas yang tidak akan habis terpakai. Saat pelacuran telah dianggap sebagai salah satu komoditas ekonomi (bisnis gelap) yang sangat menguntungkan, maka yang akan terjadi adalah persaingan antara para pemain dalam bisnis pelacuran tersebut untuk merebut pasar. Merujuk pada hasil penelitian Praktek Prostitusi Terhadap Penyalahgunaan Izin Spa Di Makassar Dalam Tinjauan Sosio-Ekonomi, kemungkinan untuk menjalankan bisnis yang diluar norma disebabkan adanya ketimpangan dalam melakukan pemenuhan akan kebutuhan yang menghasilkan orang-orang melakukan tindakan diluar norma dan nilai yang berlaku.

2. Faktor-faktor yang menyebabkan penyalahgunaan SPA sebagai tempat prostitusi dalam tinjauan sosio ekonomi di kota Makassar.

Alasan-alasan mengapa seseorang menjadi pelacur bisa sangat kompleks, tidak saja dari prostitusi itu sendiri melainkan juga dari keluarga dan masyarakat disekelilingnya. Tetapi secara sengaja menjadi prostitusi jarang dijumpai sebagai salah satu factor penyebab karena bagaimanapun pekerjaan ini dianggap bertentangan dengan normal. Berbeda dengan pendapat di atas, Greenwald (Koentjoro, 2004: 53) 
mengemukakan bahwa faktor yang melatarbelakangi seseorang untuk menjadi pelacur adalah faktor kepribadian. Ketidakbahagiaan akibat polahidup, pemenuhan kebutuhan untuk membuktikan tubuh yang menarik melalui kontak seksual dengan bermacammacam pria, dan sejarah perkembangan cenderung mempengaruhi perempuan menjadi pelacur. Sedangkan Supratiknya (1995: 98) berpendapat bahwa secara umum alasanwanita menjadi pelacur adalah demi uang. Alasan lainya adalah wanita-wanita yang pada akhirnya harus menjadi pelacur bukan atas kemauannya sendiri, hal ini dapat terjadi pada wanita-wanita yang mencari pekerjaan pada biro-biro penyalur tenaga kerja yang tidak bonafide, mereka dijanjikan untuk pekerjaan di dalam atau pun di luar negeri namun pada kenyataannya dijual dan dipaksa untuk menjadi pelacur.

Terkait dengan praktek prostitusi yang terjadi secara tidak berizin di tempat-tempat usaha SPA harus dipahami secara menyeluruh bahwa Individu merupakan produk masyarakatnya. Tentu hal ini mudah dipahami jika konteks masyarakat modern sebagai pondasi msyarakat perkotaan menjadi titik ukurnya, Simbol masyarakat yang banyak terletak prestise kepada materi merupakan alasan utama individu atau usaha memilih jalan pintas. Masyarakat yang kemudian lebih menghargai materi membuat tiap individu untuk mencarikan sarana dengan jalan pintas ini. Prostitusi sebagai fenomena dalam masyarakat dapat pula diartikan sebagai sarana dalam pemenuhan kebutuhan hidup sehari-hari, pemenuhan kebutuhan hidup dapat berupa sandang dan papan (berbeda-beda tingkat kebutuhan) ini mendorong tiap individu dalam sistem kerja SPA untuk mencari tambahan atau pemasukan sampingan. Observasi awal yang dilakukan peneliti, ditemukan bahwa pemasukan tambahan dari prostitusi (pijat plus-plus, berhubungan badan) yakni Rp. 500.000 tiap sekali order.

\section{KESIMPULAN}

Setelah melakukan penelitian, maka peneliti dapat menyimpulkan beberapa kesimpulan untuk menjawab masalah yang diangkat dalam penelitian ini, kesimpulan yang dapat ditarik yaitu praktek Prostitusi terhadap penyalahgunaan izin SPA di Makassar dalam tinjauan Sosio ekonomi. yakni lebih ditutupi dengan kedok panti pijat meskipun menjadi rahasia umum bahwa panti pijat juga melakukan tindakan prostitusi tanpa diketahui pihak terkait atau terkesan ditutupi oleh pengelola dan terlebih juga adanya kerjasama dengan aparatur Negara, sedangkan faktor-faktor yang menyebabkan penyalahgunaan SPA sebagai tempat prostitusi dalam tinjauan sosio ekonomi di kota 
Makassar sangat dipengaruhi faktor ekonomi dan tanggung jawab sosial uang dipikul pekerja pijat plus-plus tersebut.

\section{DAFTAR PUSTAKA}

Arikunto, Suharsimi. (1996). Prosedur Penelitian Suatu Pendekatan Praktek. Jakarta: PT Rineka Cipta.

Ali, Muhammad. (1989). Penelitian Kependidikan Prosedur \& Strategi. Bandung: Angkasa.

Abdul hak, I. (2001). Komunikasi pembelajaran: pendekatan konvergensi dalam peningkatan kualitas dan efektifitas pembelajaran. Bandung: UPI.

Abdulsyani, (2002). Sosiologi Skematika, Teori, Dan Terapan. Jakarta: PT Bumi Aksara.

Abu Ahmadi \& Supriyono Widodo. (2004). Psikologi Belajar. Jakarta: PT Rineka Cipta.

Basrowi dan Soenyono. (2004). Teori Sosial Dalam Tiga Paradigma. Surabaya: Yayasan Kampusiana.

Blau, Peter M. (1987). Birokrasi dalam masyarakat modern.Edisi kedua. Jakarta: UI press

Bagong, Suyanto J. Dwi Narwoko. (2004). Sosiologi Teks Pengantar dan Terapan. Jakarta: Kencana Media Group

Basuki, Sulistyo. (2010). Metode Penelitian. Jakarta : Penaku.

Bungi,burhan. (2007), Penelitian Kualitatif, Jakarta : Carolina Nitimihardjo, Jusman

Iskandar. (1993). Dinamika Kelompok. Bandung: Sekolah Tinggi Kesejahteraan Sosial

Carolina Nitimihardjo, Jusman Iskandar. (1993). Dinamika Kelompok. Bandung: Sekolah Tinggi Kesejahteraan Sosial

Gerungan, W.A, (1996). Psikologi Sosial, Bandung. Eresco.

Gerungan, W. A.(2004). Psikologi Sosial. Bandung: PT. Refika Aditama

George, Ritzer dan Douglas J Goodman.(2003). Teori Sosiologi Moderen (edisi keenam). Jakarta: Penerbit Kencana.

Hendro puspito. (1989). Sosiologi Semantik. Kanisius: Yogyakarta.

Hendro Puspito. (1992). Sosiologi Agama. Jakarta : Penerbit Kanisius.

Huraerah dan Purwanto. (2006). Dinamika Kelompok: Konsep dan Aplikasinya. Bandung: PT Rafika Aditama. 
Johnson, Doyle Paul. (1986). Teori Sosiologi Klasik dan Modern. Jakart: PT. Gramedia.

Koenjaraningrat. (1993). Metode-Metode Penelitian Masyarakat, edisi ke tiga. Jakarta: Gramedia

Mardalis. (1989). Metode Penelitian Suatu Pendekatan Proposal. Jakarta: Bumi Aksara.

Moleong.LJ (2012). Metodologi penelitien kualitatif edisi revisi. Bandung:PT Remaja Rosdakarya

Muchlas, Makmuri. (2005). Perilaku Organisasi. Yogyakarta : Gadjah Mada University Press.

Mangkunegara, AA. Anwar Prabu. (2008). Perencanaan dan PengembanganSumber Daya Manusia. Cetakan Ketiga. Bandung: PT. Rafika Aditama.

Narwoko ,J Dwi Dan Suyanto Bagong. (2006) . Sosiologi Teks Pengantar Dan Terapan ,Jakarta:Kencana

Soemardjan, Selo Dan Soleman, Soemardi (Ed). (1974). Setangkai Bunga Sosiologi. Jakarta:Yayasan Badan Penerbit Fakultas Ekonomi UI.

Soekanto, Soerjono. (2010). Sosiologi Suatu Pengantar .Cet ke-43;Jakarta : Rajawali Press

Soekanto, Soerdjono. (1983). Faktor-faktor Yang Mempengaruhi Penegakan Hukum. Jakarta: PT. Raja Grafindo Persada.

(1984). Pengantar Penelitian Hukum, Universitas Indonesia.

Suyanto,j.swi Narwoko Dan Bagong (2011), Sosiologi Teks Pengantar Dan Terapan, Edisi keempat ,cet ke-5 ; Jakarta Kencana

Soedjono ,D.1982 . Phatologi Social. Bandung.

Subakti,A.Ramlan Dkk. (2011). sosiologi teks pengantar dan terapan.jakarata prenada media group.

Santoso, Slamet. (2010). Teori-teori psikologi sosial. Bandung: Refika Aditama

Soejono soekanto.(1982) . Sosiologi Suatu Pengantar, jakarata :PT raja grafindo

Sugiyono 2012. Memahami Penelitian Kualitatif. Bandung:Alfabeta

Tim penyusun Fkip Unismuh. 2015. Pedoman Penulisan Skripsi. Unismuh Makassar: Panrita Press.

Usman Husain dan Setiady Purnomo. (1995). Metode Penelitian Sosial. Bandung: Bumi Aksara. 
Taneko, soleman B, (1986). Konsepsi System Sosial dan System Sosial Indonesia.Jakarta : Fajar Agung

Watloly. (2005). Tanggung Jawab Pengetahuan : Mempertimbangkan Epistemology Secara Cultura, Jakarta: Balai Penerbit FK UI. 